\title{
Internet for Children: a Review Study
}

\author{
Dita Rachmayani
}

University of Brawijaya, Malang, Indonesia

Corresponding e-mail: dh33ta@ub.ac.id

\begin{abstract}
Today, internet is easily accessible use not only for adolescent and adult, but also for children. The purposed of this study is to describe about the activity, benefit, risk, and also protective factors about children internet use. This study is a literature review, used of relevant 20 research article (from 2001-2016) around the theme research about children internet use from Jstor, Science direct and sage publication. The results showed that children use internet for entertainment purpose, such as online games, listening music, and watching video. Children also use internet for searching information and social online interaction. This activity can facilitate social and cognitive development for children, but there are negative impact such as internet addiction, decreased vision skills, and get extreme information. Therefore, parenting role and guide is important to control children internet use, supported internet literacy education at home and school.
\end{abstract}

Keywords: children, internet, protective, risk

\section{INTRODUCTION}

The recent years, internet usage in Indonesia is increased. Not only in adolescent and adult users, but also in children. Based on Kominfo and UNICEF research, $80 \%$ adolescent and children in Indonesia is internet user (Kominfo \& UNICEF, 2013). This situation refer to the term of "digital native" from Prensky (2001) or "net generation" from Tapscott (2009), that today, child development along with the rapid technogical developments. Since childhood, they have been around and using technology, like computer, games online, smartphone, and also internet. So the internet has become part of their life.

Many benefit for human since the rise of internet, such as online interaction, current information, like health information (Gray, klein, Noyce, Sesselberg, \& Cantrill, 2005), entertainment, like listening musik and games online (Kraut, et al., 1998). However, internet use overtime can have negative impact.

Some research revealed the risk of internet use, either pyshical, psychological and social. Young (1999) found that excessive internet use tend to internet addiction, which have an impact on reduced of contact with family members. Internet addiction also have an impact on their performance at school, where students prefer activities conducted via Internet, such as chat, online games or other so academic self-efficacy and academic achievement decreases (Young, 1999; Odaci, 2013). Individuals may also feel lonely because less direct social contact with other people and can bring into a depression (Kraut et al, 1998; Kim, Ryu, Chon, Yeun Choi, Seo, and Nam, 2006). It can also be impaired Attention Deficit Hyperactivity Disorder (ADHD), and social anxiety disorder (Yen, Ko, Wu, and Yang, 2007; Cao, Su, Liu, \& Gao, 2007; Ha, Kim, Bae, Bae, Kim, Sim, Lyoo, \& Cho, 2007; Bernardi \& Pallati, 2009).

Some of these studies was focused on internet use in adolescents and adults, while in children are still very rare. Therefore, this study aims to map out some research related to children's internet usage, benefits, risks and protective factors.

\section{CHILD DEVELOPMENT}

According to Santrock (2011) there are three period of child development: early childhood, middle and 
late childhood. In every period of these developments, there is the task of development and change both physical, cognitive and social in children. During early childhood period ( 2 to 5 years age) young children learn to become to care for themselves, develop school readiness skill and play with peers. They also have their own cognitive process about their action and social environment, like observation, imitation, reward and punishment. Therefore, during middle and late childhood period (6 to 11 years age), they have to improve some skills like reading, writing and arithmetic.

\section{INTERNET USE IN CHILDREN}

How can children use the internet? There are several factors that make the Internet attractive and can be used by children, such as easy access and a pleasant of online activities for children.

\section{1 $\quad$ Easy Access}

Easy access of information was useful facilities for children at school and at home. Parents who allow their children to use internet. Research Johnson (2010) found that children tend to prefer the use of the internet at home and the use of the effect on the cognitive development of children. There is a possibility when at home, the child has more flexibility to access and also in a longer duration than at school. Meanwhile, at school, children use internet for learning so can searching information or using email.

Based Kominfo \& UNICEF (2013) tool used to access the internet among children is a computer (69\%), laptops (34\%) and smartphones (52\%). However, Internet use can be different, the easy internet access is currently only felt in urban areas than in rural areas. In Indonesia, almost all public facilities in urban areas have a wifi network to enable individuals to access the Internet for free.

\subsection{Activity}

In Indonesia, until the 1990s, after school, children going out with his friends to play together and interaction among other. But this time the condition will be rare. This is due to the child "net generation" tends to use internet as a fun activity for them. With using Internet, the needs of children are met, such as obtaining entertainment (play online games, listen to music, see videos), searching information related to the task at school, and also interact socially (Valkenburg \& Soeters, 2001; Kominfo \& UNICEF,
2013; Umar, David, Hasan, Jusang, \& Teimmouri, 2014).

\section{BENEFIT AND RISK OF INTERNET USE FOR CHILDREN}

As already explained, that the Internet is becoming one of the children needs at this time. Play and interaction with others can easily with using internet. In addition, the internet is also to develop themselves (Umar, David, Hasan, Jusang, \& Teimmouri, 2014). There are some benefits and also risks that could be avoided if children use Internet.

\subsection{Benefit of internet use}

Viewed from a fun activity for children using the Internet are looking for information, play and interaction with other (Umar, David, Hasan, Jusang, \& Teimmouri, 2014). In fact, according to Chen, Liu and Wang (2013) children who were satisfied in using the Internet tend to have positive affection. Based on these activities can be drawn several advantages of using Internet.

\subsubsection{Getting information}

Internet usage can be a medium of learning online, the information related to the task, as well as the latest information can impact the cognitive development and academic and perceptions that occur in the surrounding environment (Valkenburg \& Soeters, 2001; Subrahmanyam, Greenfield, Kraut, \& Gross, 2001; Johnson, 2010).

Accessible information from internet, make user should be able to selective choose information, especially for children. For example, children can search information related to the task using Internet, but usually there are advertisements for adult (pornographic) or advertising can spread the virus in computer. So it is not in accordance with the information they need.

\subsubsection{Increase Cognitive Function}

Meanwhile, the online activity was able to increase the ability to plan, visual perception, auditory memory, language expression in children (Johnson, 2010). It also did not separated from the role of parents in providing direction and communicate directly about the children internet activities. So they can develop the skills cognitive function. 


\subsubsection{Building Relation with other}

The number of social media that can be used easily to interact either with friends or with others online can improve social development and relationships (Subrahmanyam, Greenfield, Kraut, \& Gross, 2001).

It can have a positive impact for children to communicate with friends who had known so that the function of social media can facilitate indirect communication.

Meanwhile, social media can have a negative impact on a child if they open to communicate with individuals who are not yet known. So they are may be able to openly tell about his personal life or online sexual harassment can occur.

\subsection{Risk of internet use}

Meanwhile, internet use have some risk for children, such as:

\subsubsection{Tendency of Psychological Disorders}

When children do excessive internet use, they tend to have psychological disorder.Young (1999) found that internet addiction, have negative impact for children. Internet addiction can decreased academic achievement in children. Lan \& Lee (2013) found that $39.2 \%$ of variables that affect the individual become to internet addiction is based on the frequency and timing of Internet use in excess, depressed and male sex. Individuals who are depressed tend to avoid social situations (face-toface), so the Internet can make it comfortable,

In addition, there are Attention Deficit Hyperactivity Disorder (ADHD), and social anxiety disorder (Yen, Ko, Wu, and Yang, 2007; Cao, Su, Liu, \& Gao, 2007; Ha, Kim, Bae, Bae, Kim, Sim , Lyoo, \& Cho, 2007; Bernardi \& Pallati 2009) predicted to arise from internet use. Individuals feel comfortable to interact with others via the internet, and feel uncomfortable when social interaction directly.

\subsubsection{Less of Internet Literacy}

Children were able to use internet, but they haven't internet literacy. Based on research Yan (2009) of children aged 9-13 years haven't understanding of technical and social regulate the acquisition of information obtained from Internet. While the information obtained from the Internet open spread even to information should be consumed for adults. For example, shows pornographic sites, or social media containing information on violence, sexual and other behaviors (Valkenburg \& Soeters, 2001). Meanwhile, these sites can affect the child's cognitive development. Especially children are learning to observation and imitation the behavior.

In addition, the problem of children's internet usage when there are virus in their computer (Valkenburg \& Soeters, 2001). So their online activity searching information related to the task becomes disturbed.

\subsubsection{Decrease Visual function}

Excessive internet use also can decrease children visual function. Exposure to the light from the computer screen, laptop or smartphone in a long duration can reduce the power of vision (Bener, $\mathrm{Al}$ Mahdi, Vachhani, Al-Nufal, and Ali, 2010).

\section{PROTECTIVE FACTORS}

Based on risk of children internet usage, while they may not understand the potential dangers of internet use, (ey \& cupit 2011), the environment around children have an important role to protect the risk.

\subsection{Parent}

The family is a system that develops early in children, especially the parent role. The attitude of parents towards children internet use is based on age, education and residence environment (Alvarez, Torres, Rodriguez, Padilla, and Rodrigo, 2013). Parents who use internet on a tablet or smartphone in everyday life can make their children also tend to use internet (Mascheroni \& Olafsson, 2015).

Parents understand that the Internet can support learning their children, but on the other hand, they also understand that Internet use can adversely affect their children so that parents feel anxious. Tripp (2010) suggested that anxious parents and negative perceptions of internet for their children caused the opportunity to interact with foreigners, there are extreme online information (sex, violence), sexual predators and also inability to control their children internet use and other online content that can lead to negative affective (Zotova \& Zinchenko, 2014).

Parents anxiety depending at age and gender their children. Where the children with a young age tend to be considered to lack the ability to using internet (Sorbing, 2012).

Attitudes and dimensions given parents depending on age, education, place of residence which affect the digital divide (the ability of the 
parent). Parents will be giving a protective stance in older children because of the intensity of the internet use is higher. The ability of parents in the use of the internet can help guide the children (Alvarez, Torres, Rodriguez, Padilla, and Rodrigo, 2013).

Meanwhile, parents who have the experience and ability to use internet can help to guide their children internet use (Sorbing, 2012). Parents can monitor their online activity by look at the history of websites visited after the children using internet. There are differences in the role of father and mother in influencing children internet use. Father parenting effect on the expression of language, visual perception and auditory memory. Meanwhile, if the dominant learning from mother is likely to be high on metacognitive planning (Johnson, 2010).

Parenting children internet use applied depending on the age of the child. In children with a young age, the authoritative parenting style will do, and as time goes parenting turn out to be permissive to the laissez-faire (Lee, 2012; Ozgur, 2016). Parenting will influence the preventive measures of child's internet use, for example by looking at the history of children online, as well as talking to see what children do online. In addition, parents can also apply rules on children. Kids are allowed to use the Internet if it has been working on a task, while maintaining health and rest (Goh, Bay, \& Chen, 2015). This means that children do not neglect other activities and spend time only on online activities.

\section{$5.2 \quad$ Teacher}

Internet use in children is not limited at home, but also at school. Therefore, it should be an emphasis on internet literacy education for children to protect their online activity (Ey \& cupit, 2011; Yan, 2009). In Hong Kong, the introduction of ICT (Information and Communication Technology) has been incorporated into the curriculum of pre-school, because it is through technology can help explore the potential of children early, and also on children with special needs (Loo, 2012).

\section{CONCLUSION AND RECOMMENDATION}

Based on several studies, there are using quantitative and qualitative research. The participant is children or parents. Meanwhile, for research experiments conducted by Loo (2012) performed on children ages kindergarten in developing a program (software) to help children with special needs to learn internet use.
These studies have contributed much general picture of children internet use, such as the impact of positive and negative impacts, and the role of parents in assisting online activity in children. The role of parents and teachers through mentoring can improve the understanding of digital, so the negative impact of Internet usage can be reduced. Children can learn to prevent select links that are not worthy to be consumed because it can harm the computer access. In addition, during the period of child development, using internet can facilitate cognitive development such as language and memory. For example in the pre-school children can be introduced on the colors, fonts, and the names of animals through the game online.

In the future research could focus on the evaluation of the use games for children, especially pre-school age. This is due at this time parents tend to let the children use the Internet to watch videos or play games. However, the limited research related to the impact on children, whether positive impact such an increase in cognitive abilities or have a negative impact as less direct communication with other children.

Internet provides a lot of influence in children development. Therefore, in order to increase internet use that can provide benefits to the children development, should start their early education about internet literacy from home and school. The role of parents and teachers in assisting the online activities, giving advice would malicious sites, and also control the frequency and duration of children internet use. So the risk of internet usage can be reduced.

\section{REFERENCES}

Alvarez, M., Torres, A., Rodriguez, E., Padilla , S., \& Rodrigo, M. J. (2013). Attitudes and parenting dimensions in parents' regulation of Internet use by primary and secondary school children. Computers and Education, 67, 69-78.

Bener, A., Al-Mahdi, H. S., Vachhani, P. J., AlNufal, M., \& Ali, A. L. (2010). Do excessive internet use, television viewing and poor lifestyle habits affect low in school children? Journal of Child Health Care, 14 (4), 375-385.

Bernardi, S., \& Pallati, S. (2009). Internet addiction : A descriptive clinical study focusing on comorbidities and dissociative symptoms. Comprehensive Psychiatry,50(6), 510-516. retrieved from : http://dx.doi.org/10.1016/j.comppsych.2008.11 .011 .

Cao, F., Su, L., Liu, T., \& Gao, X. (2007). The relationship between impulsivity and internet 
addiction in a sample of Chinese adolescents. European Psychiatry, 22(7), 466-471. retrieved from : http://dx.doi.org/10.1016/j.eurpsy.2007.05.004.

Chen, C.-X., Liu, R.-D., \& Wang, D. (2013). Why are children attracted to the internet? The role of need satisfaction perceived online and perceived in daily real life. Computers in Human Behavior, 29, 185-192.

Ey, L.-A., \& Cupit, C. G. (2011). Exploring young children's understanding of risks associated with Internet usage and their concepts of management strategies. Journal of Childhood Research, 9 (1), 53-65.

Goh, W. W., Bay, S., \& Chen, V. H.-H. (2015). Young school children's use of digital devices and parental rules. Telematic and Informatic, 32, 787-795.

Gray, N., klein, J., Noyce, P., Sesselberg, T., \& Cantrill, J. (2005). The internet : A window on adolescent health literacy. Journal of Adolescent Health, 37(3), 243.e1-243.e7. retrieved from : http://dx.doi.org/10.1016/j.jadohealth.2004.08. 023.

Johnson, G. M. (2010). Internet use and child development : Validations of the ecological techno-subsystem. Educational Technology \& Society, 13 (1), 176-185.

Johnson, G. M. (2010). Young children's Internet use at home and school: Patterns and profiles. Journal of Early Childhood Research, 8 (3), 282-293.

Kim, K., Ryu, E., Chon, M., Yeun, E., Choi, S., Seo, J., \& Nam, B. (2006). Internet addiction in Korean adolescents and its relation to depression and suicidal ideation : A questionnaire survey. International journal of nursing studies, 43(2), 185-192. retrived from : http://dx.doi.org/10.1016/j.ijnurstu.2005.02.00 5.

Kominfo \& UNICEF. (2013). Digital citizenship safety among children and adolecents in Indonesia. Retrieved from Kominfo: https://www.google.co.id/url?sa=t\&rct=j\&q=\& esrc $=$ s\&source $=$ web $\& c d=1 \& c a d=r j a \& u a c t=8 \&$ ved $=0$ ahUKEwicut $29 \mathrm{~s}-$

jOAhWBRI8KHeUoAm4QFgghMAA\&url=htt ps $\% 3 \mathrm{~A} \% 2 \mathrm{~F} \% 2 \mathrm{Fweb}$. kominfo.go.id\%2Fsites $\%$ 2 Fdefault $\% 2$ Ffiles $\% 2$ Fusers $\% 2$ F $12 \% 2$ FKomin fo-

Presentasi\%2520Laporan\%2520Hasil\%2520Pe nelit

Kraut, R., Lundmark, V., Patterson, M., Kiesler, S., Mukopadhyay, T., \& Scherlis, W. (1998). Internet paradox : A social technology that reduces social involvement and psychological well-being. American Psychologist (53)9, 1017-1031. retrieved from : http://dx.doi.org/10.1037//0003066X.53.9.1017.

Lan, C. M., \& Lee, Y. H. (2013). The predictors of internet addiction behaviors for Taiwanese elementary schools students. Social Psychology International, 34 (6), 648-657.

Lee, S.-J. (2012). Parental restrictive mediation of children's internet use : Effective for what and for whom? New Media \& Society, 15 (4), 466481.

Loo, A. (2012). Internet surfing for kindergarten children: A feasibility study. Gifted Educational Education, 28 (2), 176-184.

Mascheroni, G., \& Olafsson, K. (2015). The mobile Internet: Access, use, opportunities and divides among European children. New Media \& Society, 1-23.

Odaci, H., \& Kalkan, M. (2010). Problematic internet use, loneliness and dating anxiety among young adult university students. Computers \& Education, 55, 1091-1097.

Ozgur, H. (2016). The relationship between internet parenting styles and internet usage of children and adolescents. Computers in Human Behavior, 60, 411-424.

Prensky, M. (2001). Digital natives, digital immigrants. On the Horison, 9 (5).

Santrock, J. W. (2011). Life-Span Development. New York: McGraw Hill.

Sorbing, E. (2012). Parents' concerns about their teenage children's internet use. Journal of Family Issues, 25 (1), 75-96.

Subrahmanyam, K., Greenfield, P., Kraut, R., \& Gross, E. (2001). The impact of computer use on children's and adolescent development. Applied Developmental Psychology, 22, 7-30.

Tapscott, D. (2009). Grown up digital: How the net generation is changing your world. New York: McGraw Hill.

Tripp, L. M. (2010). The computer is not for you to be looking around, it is for schoolwork': Challenges for digital inclusion as Latino immigrant families negotiate children's access to the internet. New Media \& Society, 13 (4), 552-567.

Umar, S. Z., Daud, A., Hasan, S. M., Jusang, B., \& Teimmouri, M. (2014). Children internet usage : Opportunities for self-development. Procedia Social and Behavioral Sciences, 155, 75-80.

UNICEF New York, Divisions of Communication, Social and Civic Media Section Gerrit Beger, Prissilla Kounkou Hoveyda, akshay Sinha. (2012). Indonesian Youth Online : An exploratory study of the Indonesian digital landscape. New York: unicef. 
Valkenburg, P. M., \& Soeters, K. E. (2001).

Children positive and negative experience with internet: An exploratory Survey.

Communication Research, 28 (5), 652-675.

Wells, M., \& Mitchell, K. J. (2008). How do highrisk youth use the internet? Charactheristics and implications for prevention. Child Maltreatment, 3 (3), 227-234.

Yan, Z. (2009). Limited knowledge and limited resources : Children's and adolescents' understanding of the internet. Journal of Applied Developmental Psychology, 30, 103115.

Yen, J., Ko, C., Yen, C., Wu, H., \& Yang, M. (2007). The comorbid psychiatric symptoms of internet addiction : Attention deficit and hyperactiviy disorder (ADHD), depression, social phobia and hostility. Journal of adolescent health,41(1), 93-98. retrieved from http://dx.doi.org/10.1016/j.jadohealth.2007.02. 002.

Zotova, O. Y., \& Zinchenko, Y. P. (2014). Parent notions of the internet information aimed at children. Procedia Social and Behavioral Sciences, 146, 61-67 